\title{
Agricultural easements: A farmland preservation tool
}

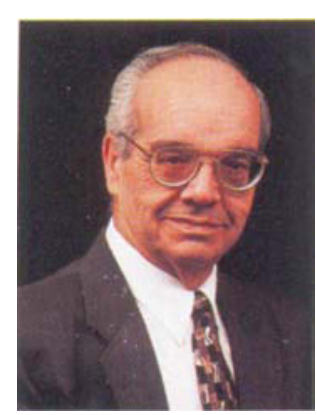

W.R. GOMES

Agriculture and

Natural Resources
Vice President

AS California's population grows, the pressures to subdivide and develop farmland increase. A recent UC Agricultural Issues Center (AIC) study reported that 497,000 farmland acres were converted to urban uses between 1988 and 1998 , as population rose by 5.4 million $(19 \%)$

The AIC study translated that figure to the development of 0.1 acres of farmland, on average, for each new resident. California's population is projected to grow to 58.7 million by 2040. If the same rate of development were to continue, the population increase would result in conversion of about 2.5 million acres of farmland to urban use by 2040 - about $10 \%$ of the 27 million acres of private farmland now in the state.

Furthermore, direct urbanization is only one form of farmland loss. Acres may be removed from production for other reasons, such as: the transfer of water from farming to environmental or urban uses; the steady expansion of wildlife habitat and wetlands restoration programs; and the retirement of land which is no longer agriculturally viable, such as salt-laden acres in western San Joaquin Valley that lack effective drainage.

Californians are exploring a variety of ways to minimize farmland loss, including "smart growth" measures that encourage more intensive urban development. For many landowners and community leaders in California, however, agricultural easements are rapidly becoming the preferred tool for protecting farmland.

In voluntarily selling or donating an easement on an agricultural parcel, a landowner gives up the rights to develop the property for more intensive urban uses, while retaining ownership for all other purposes. In return, the landowner receives cash or tax benefits, or both. As legally recorded restrictions, easements are tied to the land rather than to any individual owner. They are usually designed to exist in perpetuity.

Easement transactions occur between the landowner and a conservation organization, a nonprofit land trust or a public agency. Landowners may like the technique because of its voluntary character and economic incentives, as compared to more conventional regulations such as zoning, growth and municipal boundary controls. Conservation groups and urban residents like the presumed permanency to protect land with agricultural and other open space values.

Easements have been employed for conservation purposes in the United States for more than a century, primarily for protecting unique natural lands such as wetlands, animal and plant habitat, riparian corridors, forests and scenic views. But their application to expressly maintain land in commercial farming, usually in relation to nearby urbanization, is a relatively recent development. California's first agricultural easement program, Marin Agricultural Land Trust, began in the early 1980s. Since then the technique has proliferated in several parts of the state, although, importantly, not in the Central Valley.

Despite the apparent attraction of agricultural easements, there are serious public policy and practical issues that could limit their widespread application.

Lasting preservation. A wise investment means locating easements to carry out particular conservation objectives - whether to protect large blocks of farmland, minimize conversion to urban uses, or redirect the pattern of urbanization away from an area's best farmland. Such strategies call for acquiring easements selectively, avoiding random and isolated easements that in time could be outflanked by urban growth.

Perpetuity. Perpetuity is the biggest obstacle to landowner acceptance of easements - the fear of reducing the options of future generations of landowners. Should changed conditions (such as markets, water, labor or regulatory climate) undercut the continuing agricultural viability of an easement-restricted parcel, one argument goes, the affected future landowner should be able to opt out of the arrangement.

Natural resources. Because much of California's farmland is a "working" rather than "natural" landscape (including, for example, chemical applications and heavy machinery use), agricultural easements may be incompatible with the protection of natural resources such as wetlands and habitat.

Funding options. California's easement programs depend largely on state and federal funding and private foundations, sources external to the counties and regions where most programs operate. Because local governments have restricted tax powers, the ability of communities to buy-in to such preservation programs is limited.

Conservation agenda. Nonprofit land trusts - usually grassroots citizen organizations, often with passionate conservation agendas - are generally the principal actors managing easements in California. They have assumed this role because public agencies may lack the funds, expertise and interest to engage in land conservation. Yet land trusts are not formally accountable to the public. Their easement actions, while affecting local land-use patterns, are usually taken independent of community land-use policies.

The UC President's Advisory Commission on Agriculture and Natural Resources has described land-use issues as an area of major importance to the state. In this California Agriculture, we examine several aspects of this critical issue. The collection presents a descriptive overview of California's use of the agricultural easement technique, and provides a basis for considering new research in an important emerging area of public policy. 